\title{
Generation of Neuronal Intranuclear Inclusions by Polyglutamine- GFP: Analysis of Inclusion Clearance and Toxicity as a Function of Polyglutamine Length
}

\author{
Krista L. Moulder, ${ }^{1}$ Osamu Onodera, ${ }^{2,4}$ James R. Burke, ${ }^{2,4}$ Warren J. Strittmatter, ${ }^{2,3,4}$ and \\ Eugene M. Johnson $\mathrm{Jr}^{1}$ \\ ${ }^{1}$ Departments of Neurology and Molecular Biology and Pharmacology, Washington University School of Medicine, St. \\ Louis, Missouri 63110, and Departments of ${ }^{2}$ Medicine (Neurology), ${ }^{3}$ Neurobiology, and ${ }^{4}$ Deane Laboratory, Duke \\ University Medical Center, Durham, North Carolina 27710
}

Recent evidence suggests that, in huntingtin and many other proteins, polyglutamine repeats are a toxic stimulus in neurodegenerative diseases. To investigate the mechanism by which these repeats may be toxic, we transfected primary rat cerebellar granule neurons with polyglutamine-green fluorescent protein (GFP) fusion constructs containing 19 (Q19-GFP), 35 (Q35-GFP), 56 (Q56-GFP), or 80 (Q80-GFP) glutamine residues. All constructs, except Q19-GFP, aggregated within the nuclei of transfected cells in a length- and time-dependent manner. Although Q35-GFP expression led to the development of several small aggregates per cell, these aggregates were cleared or degraded, and the cells remained viable. In contrast, Q80-GFP expression resulted in one or two large aggregates and induced cell death. Caspase activation was observed after Q80-GFP aggregation, but inhibition of caspases with Boc-aspartyl(OMe)-fluoromethylketone (BAF) only served to delay, not prevent, toxicity. In addition, aggregation and toxicity were not affected by other modulators of neuronal cell death such as genetic deletion of the proapoptotic $b c /-2$ family member bax or addition of the protein synthesis inhibitor cycloheximide. Lastly, nuclear condensation did not occur as part of the toxicity. These data suggest that polyglutamine-GFP expression is toxic to primary neurons but that the death is distinct from classical apoptosis.

Key words: aggregation; cerebellar granule neurons; apoptosis; caspase; ubiquitin; $c A M P$
Currently, eight neurodegenerative diseases are believed to be caused by expansions in [CAG] trinucleotide-repeat regions within human genes. These expanded repeats, encoding glutamine residues, are implicated in Huntington's disease, spinobulbar muscular atrophy (SBMA), dentatorubropallidoluysian atrophy, and the spinocerebellar ataxias (SCAs). Because the proteins responsible for these diseases share no identity outside of the repeat region, the polyglutamine repeats themselves are proposed to lead to a toxic gain-of-function. Several lines of evidence support this proposal. First, all of these diseases are autosomal dominant, except for SBMA, which is X-linked (La Spada et al., 1991). Second, rare individuals who are homozygous for polyglutamine expansions do not have more severe symptoms than do heterozygous patients (Wexler et al., 1987). Third, expansions do not affect either transcription or translation of the genes and their transcripts (for review, see Sharp and Ross, 1996). Finally, genetic deletion of huntingtin in mice does not result in

Received Sept. 8, 1998; revised Oct. 21, 1998; accepted Oct. 23, 1998.

This work was supported by National Institutes of Health Grant AG12947 and Alzheimer's Disease Research Center Grant P50AG05681 to E.M.J., the Beeson Award to J.R.B., and the Deane Laboratory (O.O., J.R.B., and W.J.S.). K.L.M. is supported as a Lucille P. Markey predoctoral fellow. We thank Dr. Qiao Yan (Amgen, Thousand Oaks, CA) for BDNF, Monsanto Corporation (St. Louis, MO) for IGF-I, Dr. Anu Srinivasan (Idun Pharmaceuticals, La Jolla, CA) for CM1 antibody, and Dr. Stanley Korsmeyer (Washington University, St. Louis, MO) for bax ${ }^{-1-}$ mice. We also thank Bill Coleman for assistance with confocal microscopy and Patricia Osborne, Girish Putcha, and Dr. Mohanish Deshmukh for critical evaluation of this manuscript.

Correspondence should be addressed to Dr. Eugene M. Johnson, Jr., Department of Molecular Biology and Pharmacology, Washington University School of Medicine, 4566 Scott Avenue, Box 8103, St. Louis, MO 63110.

Copyright (C) 1999 Society for Neuroscience $0270-6474 / 99 / 190705-11 \$ 05.00 / 0$ a disease phenotype (Duyao et al., 1995; Nasir et al., 1995; Zeitlin et al., 1995).

Although the idea that these polyglutamine repeats are responsible for a toxic gain-of-function has gained considerable favor, the mechanism by which this occurs is not understood. Because each disease affects a discrete population of neurons, researchers have thought that a specific, interacting protein may exist for each that restricts the toxic effect to these neurons. However, only one interacting protein with an expression pattern that mimics the affected brain areas for that particular disease (SCA1) has been identified (Matilla et al., 1997). Alternatively, the gain-offunction could result from enhanced protein aggregation, because polyglutamine repeats form $\beta$-pleated sheet structures in vitro (Perutz et al., 1994). Polyglutamine repeats also serve as preferred substrates for transglutaminase (Kahlem et al., 1996; Cooper et al., 1997), thereby linking the polyglutamine-containing protein to surrounding proteins in the form of an aggregate. Whatever the mechanism, polyglutamine-containing proteins do form aggregates in diseased brain and in transgenic mouse models. These aggregates are referred to as "neuronal intranuclear inclusions" (NII) because of their location in the nuclei of affected neurons. In addition, NII are ubiquitinated, perhaps as a result of aborted protein recycling or degradation (for review, see Ross, 1997).

To investigate the mechanisms of polyglutamine toxicity in primary neurons, we transfected cerebellar granule neurons with polyglutamine-green fluorescent protein (GFP) fusion constructs. The resulting aggregation and toxicity were then characterized. We found that both 35-glutamine-GFP (Q35-GFP) and 80glutamine-GFP (Q80-GFP) fusion proteins formed NII. How- 
ever, only Q80-GFP expression was neurotoxic. The toxicity was not prevented by addition of the caspase inhibitor Bocaspartyl(OMe)-fluoromethylketone (BAF). Furthermore, both aggregation and cell death continued in the absence of the proapoptotic BCL-2 family member BAX. Therefore, although the neuronal death in Huntington's disease has been suggested to be apoptotic, the toxicity in this primary neuronal model system seemed to be distinct from classical apoptosis.

\section{MATERIALS AND METHODS}

Materials. Reagents were purchased from Sigma (St. Louis, MO) unless otherwise stated. BAF and Boc-threonine(OMe)-fluoromethylketone (BTF) were obtained from Enzyme Systems Products (Livermore, CA). Brain-derived neurotrophic factor (BDNF) was generously provided by Dr. Qiao Yan (Amgen, Thousand Oaks, CA), and insulin-like growth factor I (IGF-I) was generously provided by Monsanto Corporation (St. Louis, MO). The membrane-permeable cAMP analog 8-(4-chlorophenylthio)cAMP (CPT-cAMP) was used as the source of cAMP.

CM1 polyclonal antibody, a gift from Dr. Anu Srinivasan (Idun Pharmaceuticals, La Jolla, CA), was raised against the 13 amino acid peptide CRGTELDCGIETD, which is found at the C terminus of the p20 subunit of caspase 3 (Armstrong et al., 1997; Namura et al., 1998; Srinivasan et al., 1999).

Cell culture. Primary rat cerebellar granule cells were obtained via a modification of the procedure described by Levi et al. (1984). This modification has been described in detail (Miller and Johnson, 1996). In brief, timed-pregnant Sprague Dawley rats were purchased from Harlan Sprague Dawley (Indianapolis, IN). At postnatal day 7 (P7), cerebella were dissected, cut into $\sim 1 \mathrm{~mm}^{2}$ pieces, and incubated for $15 \mathrm{~min}$ in 0.3 $\mathrm{mg} / \mathrm{ml}$ trypsin (Worthington, Freehold, NJ) at $37^{\circ} \mathrm{C}$. The pieces were triturated with a fire-polished Pasteur pipette in the presence of trypsin inhibitor and spun at $500 \times g$ for 6 min. The pellet was triturated again, and the resulting cell suspension was passed through a Nitex filter (size 3-20/14; Tetko, Elmsford, NY). Cells were plated at a density of $2.3 \times$ $10^{5} \mathrm{cells} / \mathrm{cm}^{2}$ in four-well dishes (Nunc, Naperville, IL) for cell counts, in four-well chamber slides (Nunc) for immunofluorescence with conventional fluorescence microscopy, or in glass-bottom microwell dishes (MatTek Corporation, Ashland, MA) for confocal microscopy. Before plating, dishes were coated with $0.1 \mathrm{mg} / \mathrm{ml}$ poly-L-lysine. Plating medium consisted of Basal Medium Eagle (Life Technologies, Gaithersburg, MD) containing $10 \%$ dialyzed fetal bovine serum, $20 \mathrm{~mm} \mathrm{KCl}, 100 \mathrm{U} / \mathrm{ml}$ penicillin, and $100 \mu \mathrm{g} / \mathrm{ml}$ streptomycin. The neurons were maintained at $37^{\circ} \mathrm{C}$ in a humidified incubator with $5 \% \mathrm{CO}_{2} / 95 \%$ air. To reduce the number of non-neuronal cells, we added $3.3 \mu \mathrm{g} / \mathrm{ml}$ aphidicolin to the medium $24 \mathrm{hr}$ after plating.

$\mathrm{Bax}^{-1-}$ mice were generously provided by Dr. Stanley Korsmeyer (Washington University, St. Louis, MO) (Knudson et al., 1995); cultures from these animals were treated identically to the rat cultures described above except that aphidicolin was added to the medium at 36 , not $24, \mathrm{hr}$ after plating. Cerebella from $b_{a x}^{+/+}, b^{+/-}$, and $b a x^{-/-}$animals were treated as separate parallel dissections. Genotyping was performed using tail DNA from P4 animals as described previously (Deckwerth et al., 1996).

Transfection procedure. All constructs used were under the control of the cytomegalovirus promoter. pGreen Lantern-1 (Life Technologies) was used as the source of untagged GFP. Construction of the polyglutamine-GFP fusion plasmids has been described (Onodera et al., 1997). In brief, polyglutamine repeats were synthesized by PCR from human atrophin-1 cDNA. Fragments were then cloned into the pEGFP-N1 vector (Clontech, Palo Alto, CA). Sequences of all constructs were confirmed.

Granule cells were transfected essentially as described by Xia et al. (1996) using a modified calcium phosphate protocol. At $5 \mathrm{~d}$ in vitro (DIV), medium was replaced with DMEM (Life Technologies) for $1 \mathrm{hr}$. During this time, an equal volume of solution containing $0.25 \mathrm{M} \mathrm{CaCl}_{2}$ and $67 \mu \mathrm{g} / \mathrm{ml}$ DNA was added to $2 \times$ HEPES-buffered saline [274 $\mathrm{mm}$ $\mathrm{NaCl}, 10 \mathrm{~mm} \mathrm{KCl}, 1.4 \mathrm{~mm} \mathrm{Na}_{2} \mathrm{HPO}_{4}-7 \mathrm{H}_{2} \mathrm{O}$ (Fisher Scientific, Houston, TX), $15 \mathrm{~mm}$ dextrose, and $42 \mathrm{~mm}$ HEPES (free acid), $\mathrm{pH}$ 7.07] and incubated in the dark at room temperature for $25 \mathrm{~min}$. Thirty microliters of the precipitate ( $1 \mu \mathrm{g}$ of DNA) were added to each well of a four-well dish, or $90 \mu \mathrm{l}$ of the precipitate ( $3 \mu \mathrm{g}$ of DNA) was added to a glassbottom microwell dish and incubated at $37^{\circ} \mathrm{C}$ for $1 \mathrm{hr}$. Cells were washed twice with DMEM and then returned to plating medium; $800 \mu \mathrm{M} \mathrm{CAMP}$,
$100 \mathrm{ng} / \mathrm{ml}$ BDNF, $100 \mathrm{ng} / \mathrm{ml}$ IGF-I, $100 \mu \mathrm{M}$ BAF, or $100 \mu \mathrm{M}$ BTF was included in the plating medium of some cultures immediately after the transfection. Cycloheximide $(1 \mu \mathrm{g} / \mathrm{ml})$ was added to some cultures $24 \mathrm{hr}$ after transfection to allow for initial expression of the transfected constructs. Transfection efficiency was $\sim 0.2 \%$.

To quantify transfection results, we counted the number of transfected cells in a defined area of two to four wells (of a four-well dish) per construct $24 \mathrm{hr}$ after transfection. Simultaneously, the number of cells that contained fluorescent aggregates in each well was also counted. The total number of fluorescent cells and the number of cells containing aggregates in the same defined area were again counted every $24 \mathrm{hr}$ thereafter for 5-7 d after transfection. Because of excessive fluorescent debris in polyglutamine-GFP-transfected wells, the intracellular localization of aggregates was confirmed by phase-contrast microscopy. All cultures were counted by a naïve observer.

For cotransfection experiments, GFP $(67 \mu \mathrm{g} / \mathrm{ml})$ and a polyglutamineGFP fusion construct $(67 \mu \mathrm{g} / \mathrm{ml})$ were both included in the precipitate mixture. To maintain the total amount of DNA in each condition, we used GFP alone $(134 \mu \mathrm{g} / \mathrm{ml})$, Q35-GFP alone $(134 \mu \mathrm{g} / \mathrm{ml})$, or Q80-GFP alone $(134 \mu \mathrm{g} / \mathrm{ml})$ in parallel transfections. Preliminary experiments with both pGreen Lantern-1 and LacZ as markers of transfection demonstrated that over $90 \%$ of cells that expressed GFP also expressed LacZ and vice versa (data not shown).

Propidium iodide staining. Cultures plated in glass-bottom microwell dishes were washed once with PBS and then fixed in $4 \%$ paraformaldehyde (in PBS) for $30 \mathrm{~min}$ at room temperature. After another wash in PBS, cells were permeabilized in $0.5 \%$ Triton X-100 (in PBS) for $20 \mathrm{~min}$ on ice. Cultures were washed twice with PBS and incubated with the nuclear dye propidium iodide $(5 \mu \mathrm{g} / \mathrm{ml})$ and RNase $(0.1 \mathrm{mg} / \mathrm{ml}$; Boehringer Mannheim, Indianapolis, IN) in PBS for $20 \mathrm{~min}$ at $37^{\circ} \mathrm{C}$ in the dark. Finally, cells were washed twice with PBS, a drop of $2 \mathrm{mg} / \mathrm{ml}$ paraphenylenediamine in $50 \%$ glycerol was added, and a coverslip was applied. Cells were examined on a Molecular Dynamics (Sunnyvale, CA) Model 2001 confocal microscope. Note that nuclei of cerebellar granule cells occupy a large proportion of the cell volume (Ramón y Cajal, 1911; Hervas et al., 1990).

Measurement of aggregate size. Photomicrographs were taken of cells containing fluorescent aggregates $4 \mathrm{~d}$ after transfection. For either Q35GFP or Q80-GFP, at least 50 transfected cells were examined. The number of aggregates per cell was counted, and the diameter of each aggregate was measured at the widest point. The size of the aggregates was converted to micrometers using a photomicrograph of a micrometer.

Immunocytochemistry. Cultures were washed once with PBS and then fixed for $30 \mathrm{~min}$ with $4 \%$ paraformaldehyde (in PBS) at $4^{\circ} \mathrm{C}$. After fixation, cells were washed three times with Tris-buffered saline (TBS) (100 mM Tris and $0.9 \% \mathrm{NaCl}, \mathrm{pH} 7.6)$ before exposure to blocking solution (TBS containing 5\% normal goat serum and $0.3 \%$ Triton X-100) for $30 \mathrm{~min}$ at room temperature. Cells were incubated with the primary antibody (see below) in TBS containing $1 \%$ normal goat serum and $0.3 \%$ Triton X-100. Primary antibody incubation was done overnight at $4^{\circ} \mathrm{C}$. Cells were washed three times in TBS and incubated with the secondary antibody Cy3-conjugated anti-rabbit IgG (Jackson ImmunoResearch, West Grove, PA) at a dilution of 1:400 in TBS containing 1\% normal goat serum and $0.3 \%$ Triton X-100. Secondary antibody incubation was done for $2-4 \mathrm{hr}$ at $4^{\circ} \mathrm{C}$ in the dark. Cells were washed twice with TBS, a drop of $2 \mathrm{mg} / \mathrm{ml}$ paraphenylenediamine in $50 \%$ glycerol was added, and a coverslip was applied.

For CM1 labeling, cells were plated in four-well chamber slides (Nunc), and the chambers were removed before addition of primary antibody. The CM1 polyclonal antibody was used at a dilution of 1:5000. Before addition of paraphenylenediamine, cultures were stained with Hoechst $33258(1 \mu \mathrm{g} / \mathrm{ml}$; Molecular Probes, Eugene, OR) for $20 \mathrm{~min}$ at $4^{\circ} \mathrm{C}$ in the dark to visualize nuclei and were washed twice with TBS. Cells were examined by conventional fluorescence microscopy. The number of CM1-positive cells was scored by a naïve observer.

For ubiquitin labeling, cells were plated in glass-bottom microwell dishes (MatTek Corporation). The anti-ubiquitin polyclonal antibody (Dako, Carpinteria, CA) was used at a dilution of 1:100. Cells were examined by confocal microscopy. Scans of Cy3 and GFP were done separately and then attached to ensure that the aggregated GFP did not obscure the ubiquitin labeling.

Statistics. When indicated, statistical significance was determined by Student's $t$ test. All data examined were shown to pass a test for normality. 

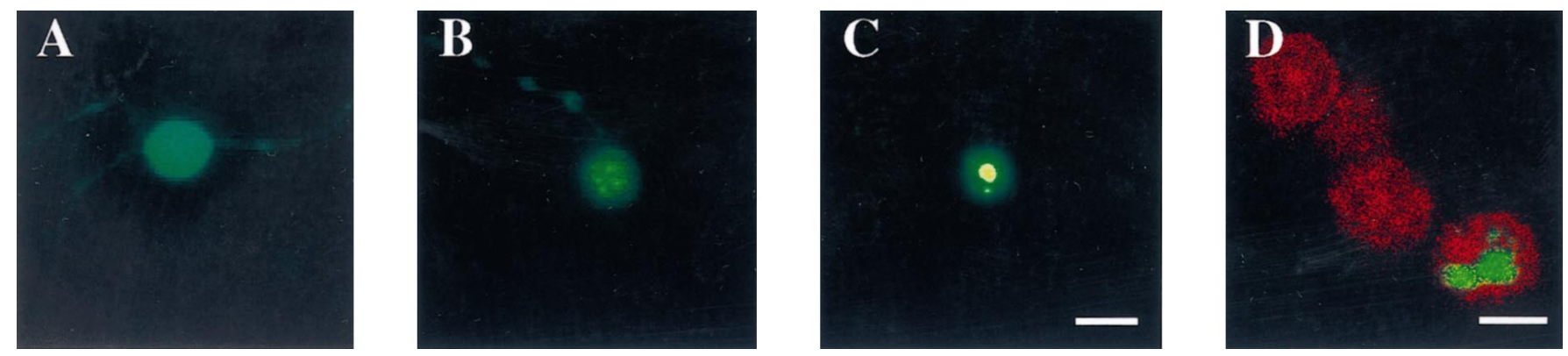

Figure 1. Polyglutamine-GFP fusion proteins aggregate in cerebellar neurons. $A-C$, At 5 DIV, cerebellar granule neurons were transfected with Q19-GFP $(A)$, Q35-GFP $(B)$, or Q80-GFP $(C)$. Photomicrographs were taken $3 \mathrm{~d}$ after transfection. $D$, Q80-GFP-transfected cells were fixed $3 \mathrm{~d}$ after transfection, and nuclei were stained with propidium iodide. The photomicrograph was taken with confocal microscopy. Scale bars: $A-C, 10 \mu \mathrm{m} ; D, 5$ $\mu \mathrm{m}$.

\section{RESULTS}

\section{Polyglutamine-GFP fusion proteins aggregate and lead to a decrease in the number of fluorescent cells in cerebellar granule neurons}

The proteins responsible for [CAG] triplet-repeat diseases do not share any homology beyond the polyglutamine-repeat region. Hence, the neurodegeneration common to these diseases is thought to be attributable to the polyglutamine repeats. For this reason, a series of polyglutamine-GFP fusion constructs was generated to characterize the generalized phenomenon of polyglutamine-containing protein oligomerization. These constructs consisted of $19,35,56$, or 80 glutamine residues fused to the $\mathrm{N}$ terminus of GFP. Both the 56- and 80-glutamine fusion proteins aggregate in COS-7 cells (Onodera et al., 1997); however, their effects in neurons have not been described. To address this, we transfected each of the constructs into rat cerebellar granule neurons. These cells were selected because they provided a relatively homogeneous population of primary neurons that was readily transfectable. Because polyglutamine-containing proteins are toxic in other culture systems (Ikeda et al., 1996), it was predicted that the polyglutamine-GFP fusion constructs might also be toxic to the granule cells. Furthermore, because the programmed cell death pathway of these neurons in response to potassium and serum deprivation has been well studied, any cell loss resulting from expression of the polyglutamine-GFP constructs in the granule cell paradigm could be compared with this apoptotic death.

At 5 DIV, cerebellar granule neurons were transfected with GFP or with the polyglutamine-GFP fusion constructs using a modified calcium phosphate protocol. The cells were then examined by fluorescence microscopy $24 \mathrm{hr}$ later. At this time, most transfected cells showed diffuse expression of GFP regardless of the construct used (Fig. $1 A$ ). However, $21 \%$ of the 80 -glutamineGFP (Q80-GFP)-transfected cells (Fig. 1C) and 5\% of the 56glutamine-GFP (Q56-GFP)-transfected cells already contained fluorescent aggregates. Confocal microscopy performed on cells stained with the nuclear dye propidium iodide revealed that the aggregates were indeed nuclear and that aggregates of Q80-GFP were sufficient to cause chromatin displacement (Fig. 1D). The nuclear localization of these aggregates was consistent with the fact that the inclusions seen in transgenic mouse models and in postmortem diseased brain are intranuclear and, thus, are referred to as NII (for review, see Ross, 1997).

Successive observation of the cells every $24 \mathrm{hr}$ revealed that a larger percentage of the Q56-GFP- and Q80-GFP-transfected cells contained aggregates over time and that some 35-glutamine-
GFP (Q35-GFP)-transfected cells also developed aggregates (Fig. $1 B$ ). By $7 \mathrm{~d}$ after transfection, $100 \%$ of Q80-GFP-transfected cells, 51\% of Q56-GFP-transfected cells, and 7\% of Q35GFP-transfected cells contained aggregates (Fig. 2A). A maximum of $29 \%$ of Q35-GFP-transfected cells was observed earlier at $96 \mathrm{hr}$ after transfection. The 19-glutamine-GFP (Q19-GFP) construct was never seen to aggregate by conventional fluorescence microscopy (Fig. $2 A$ ).

After quantification of the aggregation, the possibility that these aggregates resulted in a decrease in the number of fluorescent cells was assessed. For each construct, the number of transfected cells was counted at $24 \mathrm{hr}$; every $24 \mathrm{hr}$ thereafter, the number of fluorescent cells remaining was compared with the original number (Fig. 2B). Expression of polyglutamine-GFP fusion proteins did result in a decrease in the number of fluorescent cells over time. By 7 d after transfection, an $8 \%$ decrease occurred with GFP alone. Although the Q19-GFP construct was not seen to aggregate, there was a slightly greater decrease $(17 \%)$ than in GFP-transfected cells (statistically significant at $p<0.05$ ). Expression of the Q35-GFP, Q56-GFP, or Q80-GFP constructs resulted in a 49,56 , or $98 \%$ decrease in the number of fluorescent cells over $7 \mathrm{~d}$, respectively. Thus, in Figure $2 A$, although $100 \%$ of Q80-GFP-transfected cells contained aggregates by $7 \mathrm{~d}$ after transfection, only $2 \%$ of the transfected cells remained in the dish.

These data indicate that polyglutamine repeats in the absence of other mutant protein sequence can cause the aggregation of GFP in primary neurons. Because the time course of aggregation slightly preceded that of cell loss, this implies that fluorescent cells were apparently lost subsequent to aggregation. Moreover, both the aggregation and the resulting neuronal loss were lengthand time-dependent (Fig. 2).

\section{Differing fates of Q35-GFP- and Q80-GFP-expressing cells}

Our results in Figure 2 indicate that expression of the polyglutamine-GFP constructs induced cell death as assessed by the loss of fluorescent cells. However, a large amount of fluorescent debris that was not associated with cells was observed in polyglutamine-GFP-transfected cultures (data not shown). For this reason, it was not obvious whether the cells were dying and leaving the fluorescent aggregates in the dish or whether the cells were somehow clearing the fluorescent aggregates. If the latter were true, then cells that cleared the aggregates yet remained alive would have been scored as "lost" in Figure $2 B$. To determine whether fluorescent cells died or were lost because of clearance and/or degradation of the fluorescent aggregates, we 
A

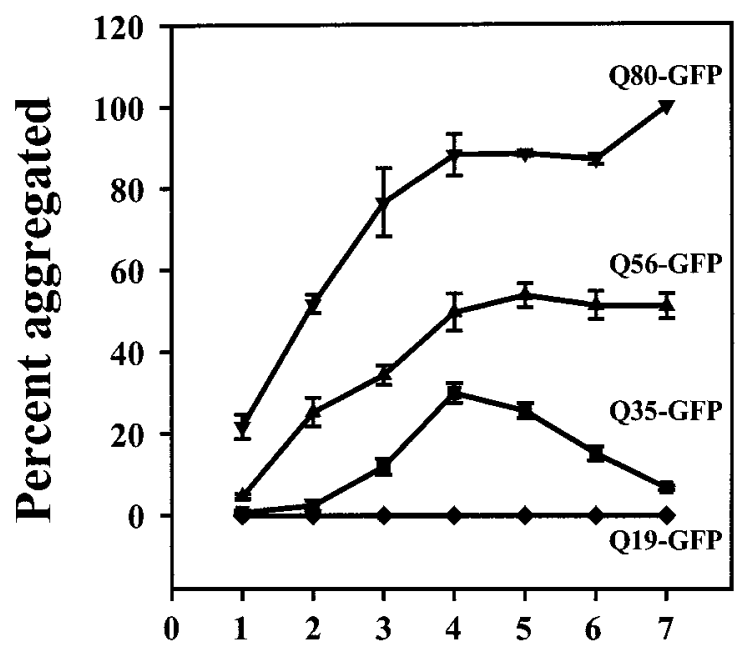

Days post-transfection
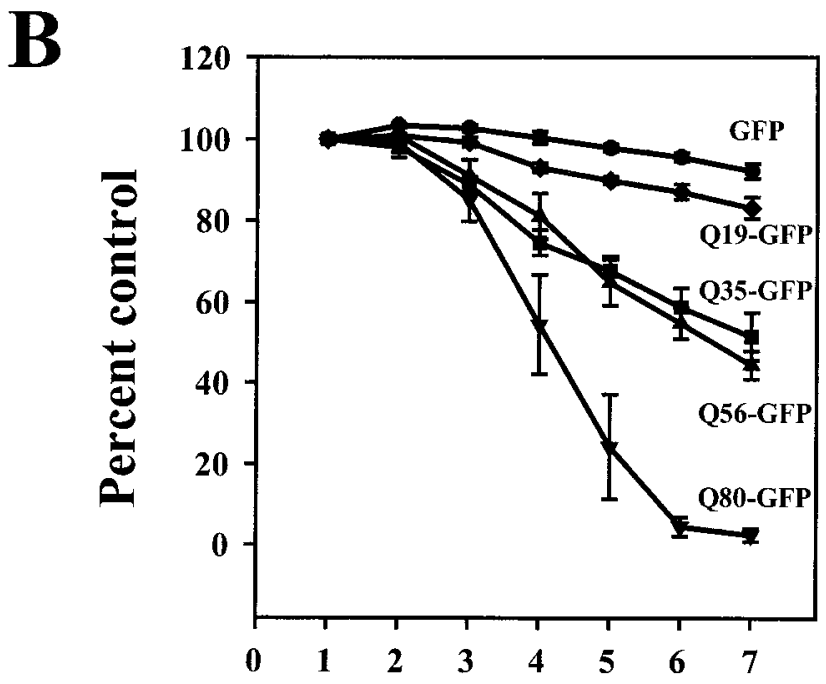

Days post-transfection

Figure 2. Polyglutamine-GFP fusion proteins aggregate and cause a decrease in the number of fluorescent cells in a length- and timedependent manner. Cerebellar granule neurons were transfected with $G F P(\bullet), Q 19-G F P(\diamond), Q 35-G F P(\square), Q 56-G F P(\mathbf{\Delta})$, or $Q 80-G F P(\nabla)$ at 5 DIV. Every $24 \mathrm{hr}$ for $7 \mathrm{~d}$ after transfection, the number of transfected cells present in designated fields and the number that contained fluorescent aggregates were counted. $A$, Data are presented as the percentage of cells at each time point that contained an aggregate. $B$, Data are presented as the number of transfected cells remaining in the field as a percentage of the original number. Error bars represent SEM; $n=3$.

cotransfected granule cells with GFP and the polyglutamine-GFP constructs. If the cells were clearing the aggregates, then the presence of GFP itself would still mark the viable cells. However, if the cells were simply dying, then neither GFP nor the fusion construct would be expressed.

Cotransfection of GFP and Q80-GFP resulted in the same rate of decrease in the number of fluorescent cells as seen with transfection of Q80-GFP alone (Fig. 3B), indicating that Q80-
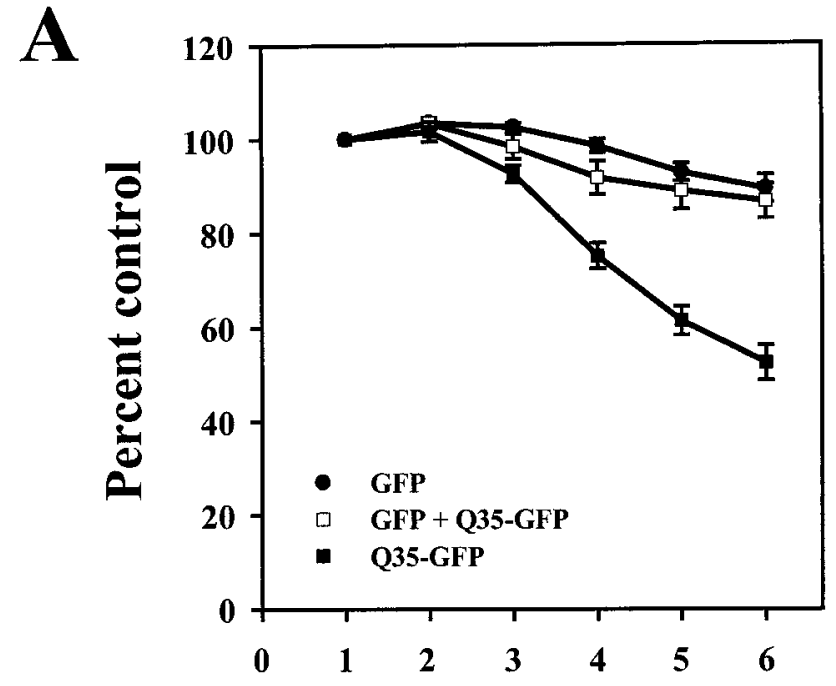

Days post-transfection

B

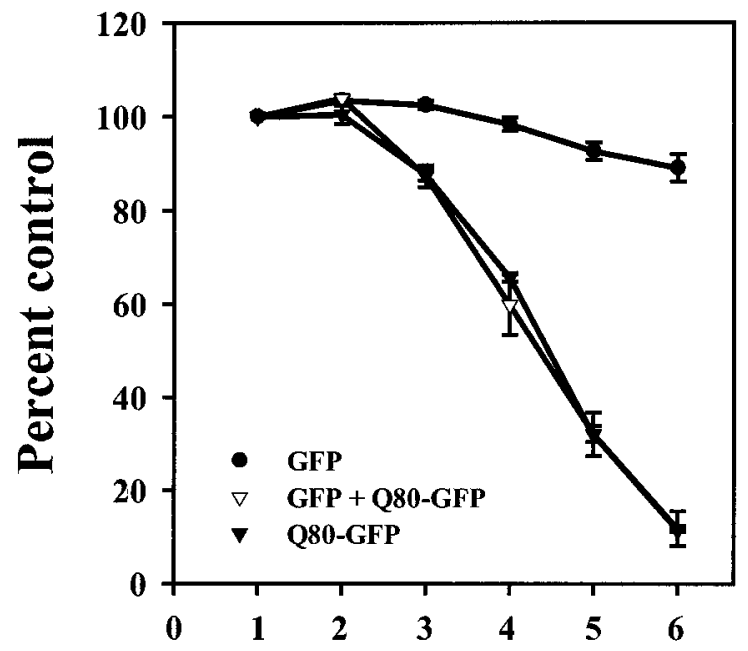

Days post-transfection

Figure 3. $Q 80-G F P$, but not $Q 35-G F P$, expression is toxic to cerebellar neurons. At 5 DIV, cerebellar granule neurons were transfected with $G F P$ $(A, B), Q 35-G F P(A), G F P+Q 35-G F P(A), Q 80-G F P(B)$, or GFP + $Q 80-G F P(B)$. Every $24 \mathrm{hr}$ for $6 \mathrm{~d}$ after transfection, the number of transfected cells present in designated fields was counted. The data are presented as the number of transfected cells remaining in the field as a percentage of the original number. Error bars represent SEM; $n=3$.

GFP expression was, indeed, killing the neurons. On the contrary, cotransfection of GFP and Q35-GFP resulted in only a $14 \%$ cell loss by $6 \mathrm{~d}$ after transfection (Fig. $3 A$ ), similar to the amount of cell loss resulting from transfection with GFP alone (11\%). Transfection of Q35-GFP alone resulted in a $48 \%$ decrease in GFPpositive cells in the same time period (Fig. $3 A$ ). These data indicate that Q35-GFP aggregates did not kill the cells but, rather, were degraded or secreted from the cells.

Because Q35-GFP aggregates did not affect granule cells in the same manner as did Q80-GFP aggregates, the two were likely different. After closer inspection, the Q35-GFP-transfected cells obviously had multiple aggregates per cell (Fig. 1, compare $B$ with 
A

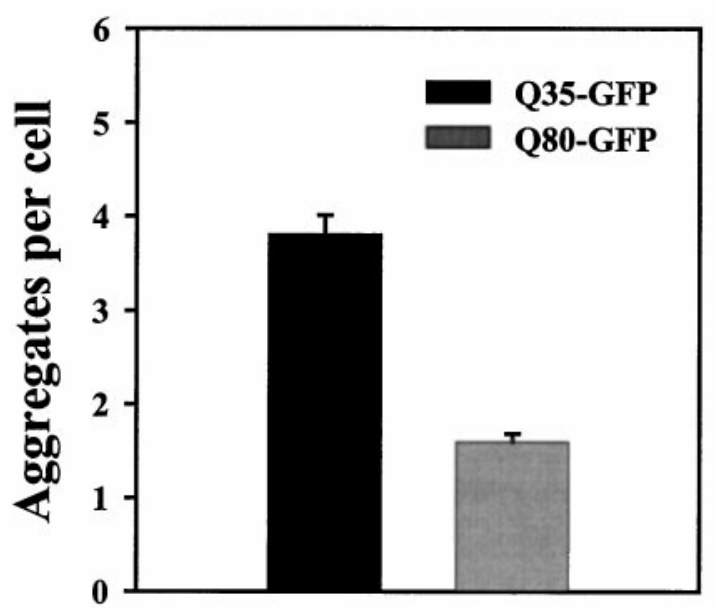

B

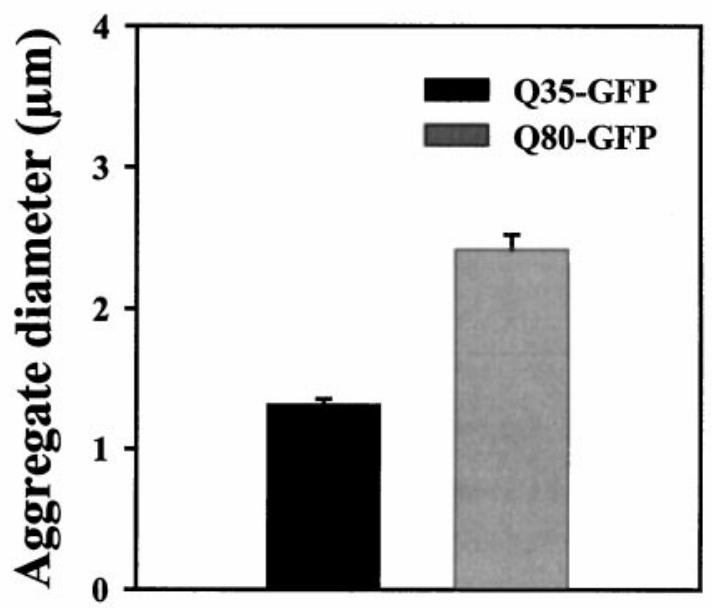

Figure 4. $Q 35-G F P$ expression results in the formation of many small aggregates per cell, whereas $Q 80-G F P$ expression results in the formation of a few large aggregates per cell. At $5 \mathrm{DIV}$, cerebellar granule neurons were transfected with $Q 35$-GFP or $Q 80$-GFP. The number of aggregates per cell was counted $(A)$, and the diameter of each aggregate was measured $(B) 4 \mathrm{~d}$ after transfection. Error bars represent SEM; $n>50$.
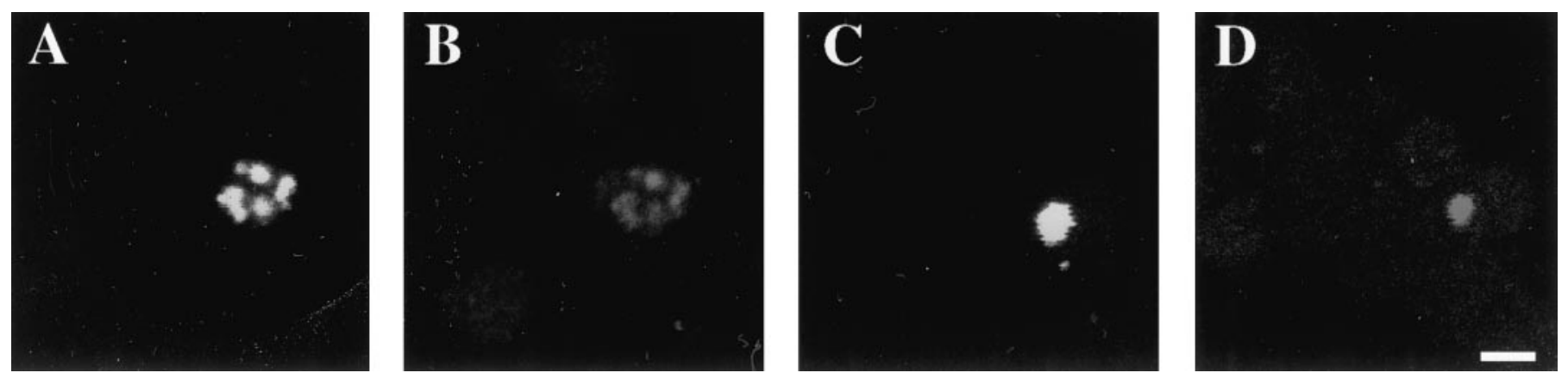

Figure 5. Both Q35-GFP and Q80-GFP aggregates are ubiquitinated. At 5 DIV, cerebellar granule neurons were transfected with Q35-GFP $(A$, $B)$ or Q80-GFP $(C, D)$. Cells were fixed $3 \mathrm{~d}$ after transfection and immunostained with an antibody specific for ubiquitin $(B, D)$. Photomicrographs were taken using confocal microscopy. Scale bar, $5 \mu \mathrm{m}$.

$C)$. To quantify this observation, we measured the number of aggregates per cell and the diameter of each $4 \mathrm{~d}$ after transfection in over 50 cells per construct. Q35-GFP transfection resulted in an average of 3.8 aggregates per cell, whereas Q80-GFP transfection resulted in an average of 1.6 aggregates per cell (Fig. 4A), consistent with the earlier observation. However, Q35-GFP aggregates had an average diameter of only $1.3 \mu \mathrm{m}$, whereas Q80GFP aggregates had an average diameter of $2.4 \mu \mathrm{m}$ (Fig. $4 B$ ). Assuming a spherical shape to the aggregates, this would correspond to a difference in total aggregate burden per cell of $1.2 \mu \mathrm{m}^{3}$ for Q35-GFP and $7.4 \mu \mathrm{m}^{3}$ for Q80-GFP. Although these data were collected $4 \mathrm{~d}$ after transfection, similar results were observed any time after Q35-GFP aggregation could be seen (data not shown). The fact that Q80-GFP resulted in larger aggregates and the fact that aggregates were seen earlier in Q80-GFP-transfected cells (Fig. $2 \mathrm{~A}$ ) indicate that the rate and extent of protein aggregation directly correlated with the length of the polyglutamine repeat.

In both postmortem diseased brain and transgenic mouse models of polyglutamine diseases, some NII are ubiquitinated (Davies et al., 1997; DiFiglia et al., 1997; Ordway et al., 1997; Paulson et al., 1997; Skinner et al., 1997; Igarashi et al., 1998). Because the ubiquitin or proteasome pathway may be responsible for the clearance of Q35-GFP aggregates, Q35-GFP and Q80-GFP aggregates were immunostained with an antibody specific for ubiquitin. At every time examined, $\sim 50 \%$ of aggregated cells showed ubiquitin immunoreactivity in both Q35-GFP- and Q80-GFPtransfected cells (Fig. 5). Although the background was diffusely labeled for ubiquitin, the immunoreactivity was concentrated at the site of aggregation. Consistently, the area occupied by the aggregate was larger than that showing ubiquitin immunoreactivity (Fig. 5, compare $C$ with $D$ ). Transfected cells that did not contain aggregates did not show increased ubiquitin immunoreactivity (data not shown).

\section{Polyglutamine toxicity is distinct from classical apoptosis}

The neuronal death that occurs in Huntington's disease (HD) has been described as apoptotic, primarily on the basis that neurons within the striatum of HD patients label by TdT-mediated dUTP nick end labeling (TUNEL) (Dragunow et al., 1995; PorteraCailliau et al., 1995; Thomas et al., 1995). For this reason, the toxicity induced by the polyglutamine-GFP fusion proteins was analyzed to determine whether it was proceeding by way of apoptosis. Caspase activation is one of the final stages of apoptosis in a number of cell death paradigms in both neuronal and 

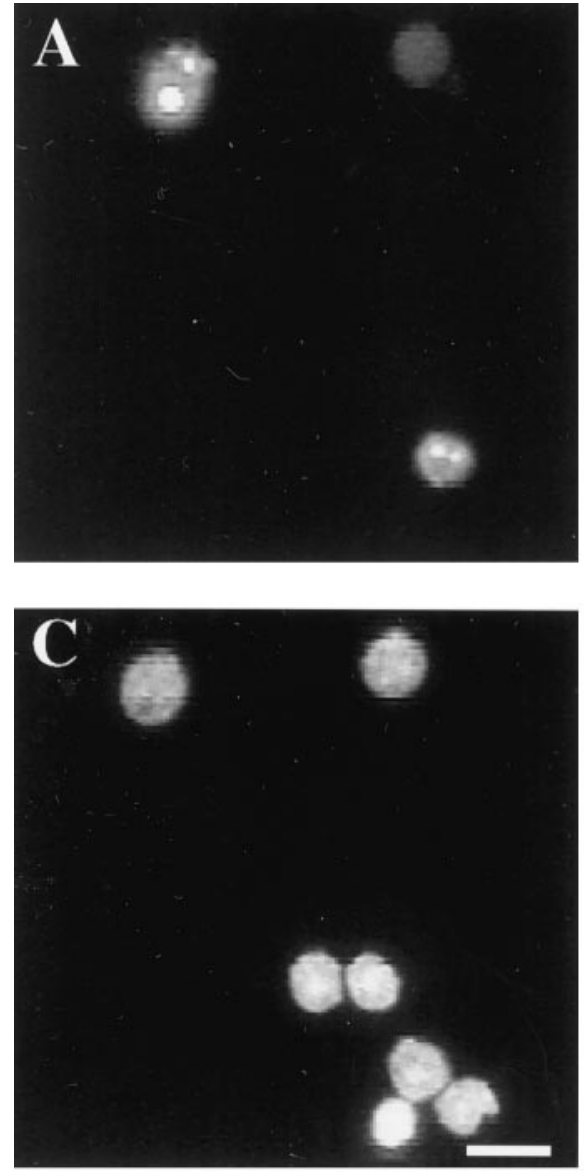

Figure 6. Neurons containing Q80-GFP aggregates show caspase activation. At 5 DIV, cerebellar granule neurons were transfected with Q80-GFP. $A, B$, Cells were fixed $3 \mathrm{~d}$ after transfection $(A)$ and immunostained with $C M 1$, an antibody specific for activated caspases 3 and $7(B)$. $C$, Nuclei were labeled with Hoechst 33258. Scale bar, $10 \mu \mathrm{m}$. $D$, Cerebellar granule neurons were transfected with $Q 35-G F P$ or $Q 80-G F P$ at 5 DIV. Every day for $5 \mathrm{~d}$ after transfection, cells were fixed and immunostained with $C M 1$. The number of cells containing aggregates and the number of CM1-positive cells were counted at each time point. The data are presented as the percentage of cells containing aggregates that were also $C M 1$-positive. Transfected cells that did not contain aggregates were never $C M 1$ positive. Error bars represent SEM; $n=3$.
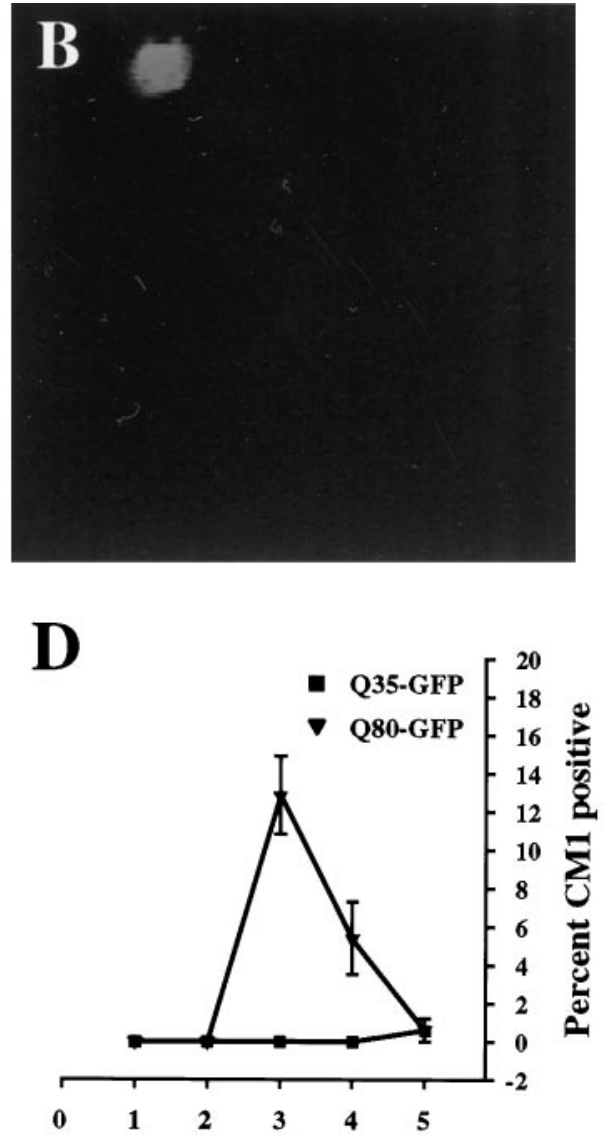

Days post-transfection non-neuronal cells. Specifically, caspase 3 (CPP32) is implicated in neuronal cell death (Kuida et al., 1996; Woo et al., 1998). Activation occurs by internal cleavage of a given procaspase into large and small subunits that together form the mature enzyme (for review, see Thornberry, 1997). To assess whether caspases were activated after expression of the polyglutamine-GFP constructs, we fixed cells every $24 \mathrm{hr}$ after transfection and immunostained the cells with the polyclonal antibody CM1. CM1 recognizes the active forms of caspases 3 and 7, such that cells without active caspases are not labeled (Armstrong et al., 1997; Namura et al., 1998; Srinivasan et al., 1998). In Q80-GFP-transfected cells, no immunoreactivity was seen in the first $2 \mathrm{~d}$ after transfection. However, on the third and fourth days, 13 and $5 \%$ of cells containing aggregates, respectively, demonstrated the presence of active caspase 3 or 7 (Fig. 6D). Transfected cells that did not contain aggregates never demonstrated increased CM1 labeling. These observations are illustrated in Figure 6; although the field contains three transfected cells, only one of the two cells containing aggregates is CM1-positive. In Q35-GFP-transfected cells, CM1 positivity was very rarely seen ( 1 cell in over 400 examined) (Fig. 6D). These data confirm that caspases were, indeed, activated in neurons after expression of a polyglutamine construct that is pathogenic in length.

Because caspases were activated in Q80-GFP-transfected cells, it was then determined whether blockade of caspase activation would be sufficient to prevent Q80-GFP-induced toxicity. The pan-caspase inhibitor BAF was added to granule cells after completion of the transfection procedure. BAF was added at a concentration shown previously to block caspase-3-like activity com- pletely in granule cells (Miller et al., 1997a). The number of GFP-positive cells was counted every $24 \mathrm{hr}$ and compared with the original number observed. Application of BAF to Q80-GFPtransfected cells slightly delayed the death of the granule cells throughout the time course of death (Fig. $7 A$ ). The effect of BAF was, in fact, the result of caspase inhibition, because the negative control peptide BTF failed to alter the time course of death. This is consistent with the effect of BAF in the death of granule cells after potassium deprivation. In that paradigm, caspases are also activated, but caspase inhibition serves only to delay the death program (Miller et al., 1997a).

The inability of BAF to block the polyglutamine toxicity completely was anticipated because of the past work in potassium deprivation-induced death. However, in Q80-GFP-transfected cells (Fig. 7B) and in Q35-GFP-transfected cells (data not shown), addition of BAF also delayed aggregation. These data suggest that the modest protective effect seen in Figure $7 A$ may be attributable to a delay in aggregation.

Although caspases were activated after Q80-GFP expression and aggregation, a number of other observations suggest that the death induced by this construct was not apoptotic. First, the death was never accompanied by nuclear condensation, often considered to be one of the hallmarks of apoptosis. Cells that contained aggregates did not have condensed nuclei, even when observed many days after transfection. Instead, the aggregates caused a displacement of the chromatin within the nuclei of transfected cells (Figs. 1, 6). This was initially noted in Hoechst 33258stained nuclei (Fig. 6), but it was thought that the aggregates could have been perinuclear and had simply masked the nuclear 
A

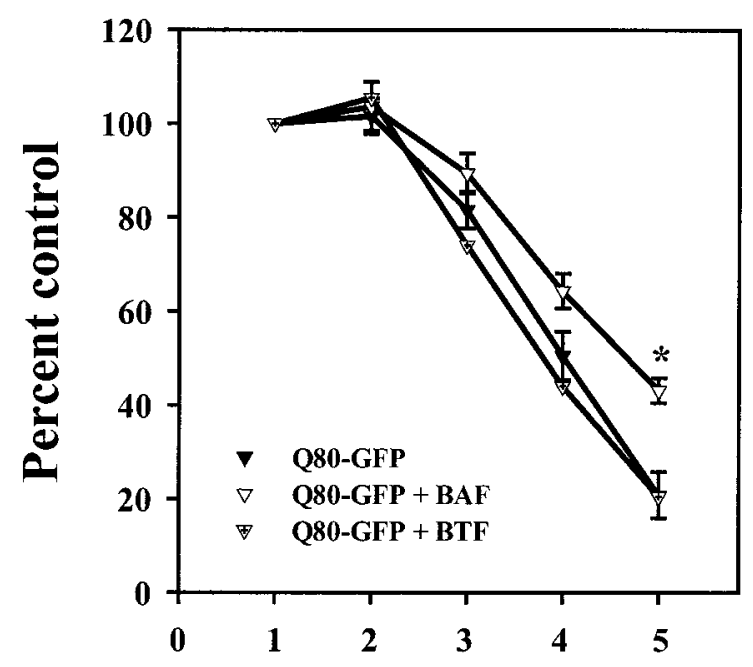

Days post-transfection

B

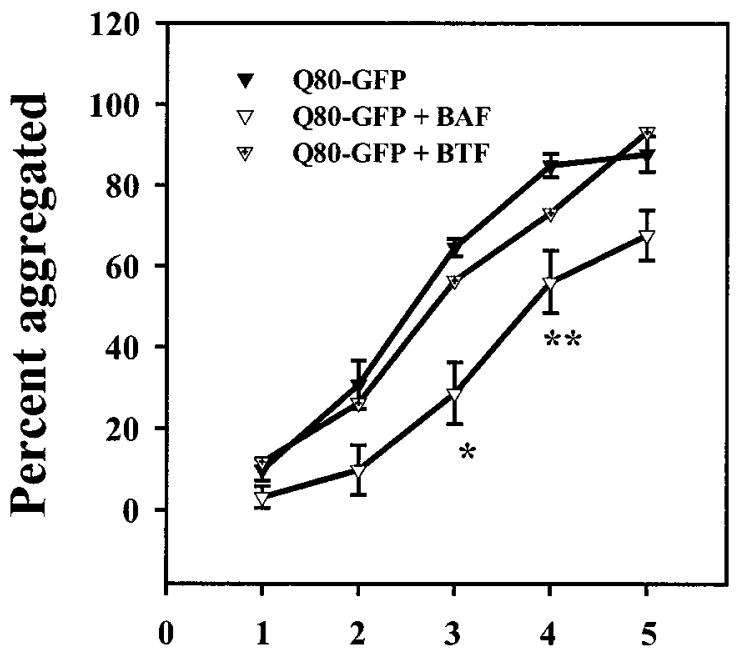

Days post-transfection

Figure 7. Addition of the caspase inhibitor $B A F$ delays both aggregation and toxicity induced by $Q 80-G F P$. At $5 \mathrm{DIV}$, cerebellar granule neurons were transfected with $Q 80-G F P$. The caspase inhibitor $B A F$ or the control peptide $B T F$ was included in some cultures. $A$, The number of fluorescent cells in designated fields was counted every $24 \mathrm{hr}$ after transfection for $5 \mathrm{~d}$. The data are presented as the number of transfected cells remaining in the field as a percentage of the original number. *, Statistically significant at $p=0.016$. $B$, The number of cells that contained fluorescent aggregates was counted every $24 \mathrm{hr}$ after transfection for $5 \mathrm{~d}$. The data are presented as the percentage of cells at each time point that contained an aggregate. *, Statistically significant at $p=0.01$;**, statistically significant at $p=$ 0.025 . For both $A$ and $B$, error bars represent SEM; $n=3$. (For BTFtreated cultures, $n=1$.)

staining. However, confocal microscopy confirmed that the aggregates were indeed nuclear, as described above (Fig. 1D).

In addition, both aggregation of the Q80-GFP construct and the concomitant toxicity occurred independently of the proapoptotic BCL-2 family member BAX (Fig. $8 A$; data not shown). Cerebellar granule neurons derived from $b_{a x} x^{+1+}$ or $b a x^{-1-}$ mice and transfected with Q80-GFP died with indistinguishable time courses (Fig. 8A), although the mouse neurons seemed to be more sensitive to Q80-GFP expression than were the rat neurons (compare Figs. 2B, $8 A$ ). BAX is required for the apoptotic death of granule cells after potassium deprivation (Miller et al., 1997a) and is also required in other neuronal cell death paradigms (Deckwerth et al., 1996; White et al., 1998). Lastly, the toxicity associated with the Q80-GFP construct was also seen in the presence of the protein synthesis inhibitor cycloheximide (Fig. $8 B$ ). Cycloheximide was added to the transfected cells $24 \mathrm{hr}$ after transfection to allow for initial expression of the construct. Therefore, although dependence on protein synthesis possibly occurred within the first $24 \mathrm{hr}$, this is unlikely because only $22 \%$ of neurons contained aggregates by $24 \mathrm{hr}$ after transfection (Fig. 2A). Although a protein synthesis-dependent step is not seen in all models of neuronal cell death, protein synthesis is required for the death of granule cells after potassium and serum deprivation (D’Mello et al., 1993).

\section{Addition of cAMP can partially protect against polyglutamine toxicity}

Although cerebellar granule cells in these experiments were maintained in depolarizing levels of potassium to maintain survival, a number of other factors have survival-promoting activity in these cultures. These include BDNF, cAMP, and IGF-I (Segal et al., 1992; D'Mello et al., 1993). For this reason, each of these was added independently to granule cells immediately after transfection to assess its effect on both aggregation and the toxicity of the Q80-GFP construct. Simultaneously, each was also added to granule cells that were deprived of potassium and serum to ensure that the factor was biologically active. Both BDNF and IGF-I were able to promote survival of granule cells, although not to the extent of potassium and serum (data not shown). However, the aggregation or toxicity in Q80-GFP-transfected cells was neither prevented nor delayed in the presence of BDNF or IGF-I (Fig. 8C, D; data not shown). Addition of cAMP, on the contrary, delayed neuronal cell loss in Q80-GFP-transfected cells without affecting the rate of aggregation (Fig. 9). Therefore, aggregation and cell death may occur simultaneously, without one causing the other.

Viable Q80-GFP-transfected cells maintained in the presence of cAMP were observed in culture for $2 \mathrm{~d}$ after all cells not treated with cAMP had died (data not shown). Curiously, the protective effect of cAMP was accompanied by maintenance of fluorescence in the neurites of transfected cells up to $4 \mathrm{~d}$ after transfection (Fig. 9D). Cells transfected with Q80-GFP in the absence of cAMP did not maintain fluorescent neurites after $2 \mathrm{~d}$ (Fig. 9C; data not shown). This further supports the idea that cAMP, but not BDNF or IGF-I, was partially protective against Q80-GFP-induced toxicity.

Because Q80-GFP-transfected neurons treated with cAMP showed a slower rate of decrease in the number of fluorescent cells than did untreated neurons, cAMP was possibly allowing for the clearance or degradation of Q80-GFP aggregates. Therefore, cotransfection of GFP and Q80-GFP was performed in the presence of cAMP. No difference was seen in the rate of decrease in the number of fluorescent cells between Q80-GFP-transfected cells and GFP- and Q80-GFP-cotransfected cells with addition of cAMP (data not shown). These data suggest that although cAMP served to delay polyglutamine toxicity, this delay did not occur via enhanced clearance or degradation of Q80-GFP aggregates. 


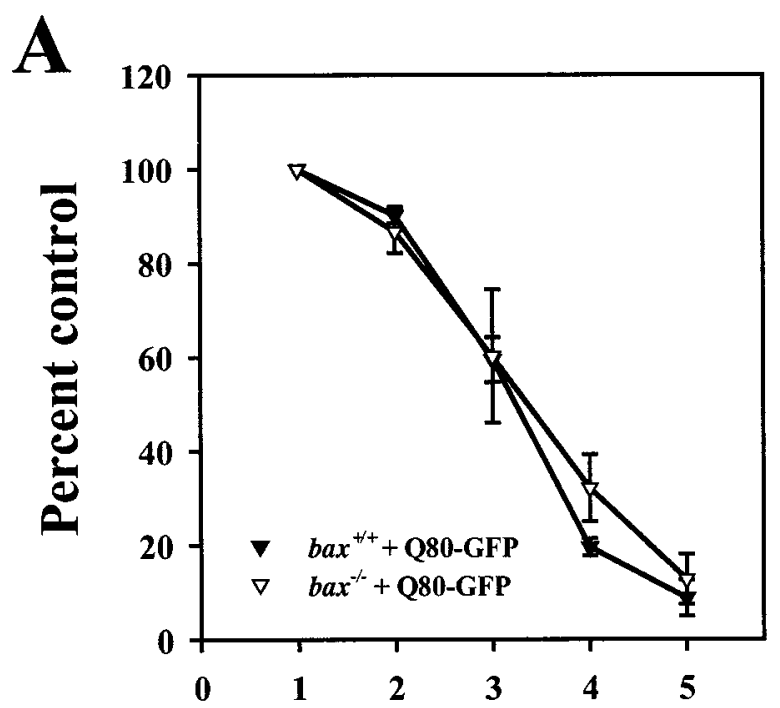

Days post-transfection

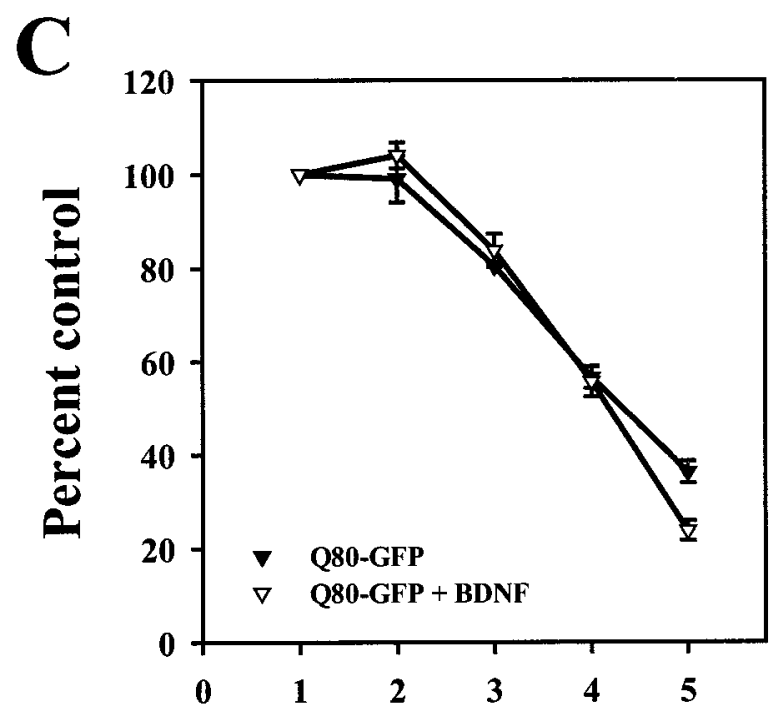

Days post-transfection

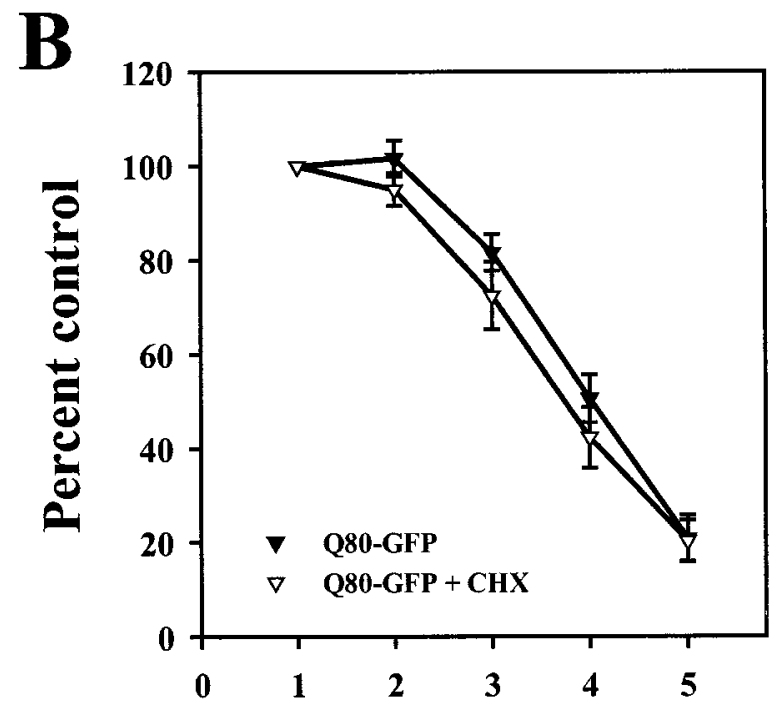

Days post-transfection

D

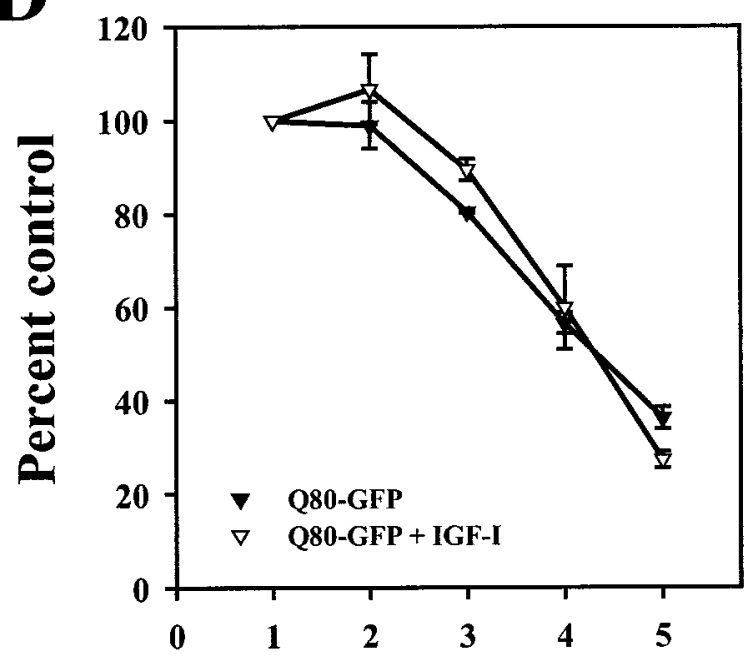

Days post-transfection

Figure 8. Polyglutamine-GFP toxicity is not affected by bax deletion or by the addition of cycloheximide, BDNF, or IGF-I. At 5 DIV, cerebellar granule neurons were transfected with $Q 80-G F P$. Every $24 \mathrm{hr}$ for $5 \mathrm{~d}$ after transfection, the number of fluorescent cells present in designated fields was counted. The data are presented as the number of transfected cells remaining in the field as a percentage of the original number. $A$, Mouse neurons from $b a x^{+/+}$ and bax $^{-1-}$ animals were transfected in parallel. $B$, Cycloheximide $(C H X ; 1 \mu \mathrm{g} / \mathrm{ml})$ was added to some cultures $24 \mathrm{hr}$ after transfection. $C, D, B D N F$ $(100 \mathrm{ng} / \mathrm{ml})$ or $I G F-I(100 \mathrm{ng} / \mathrm{ml})$ was added to some cultures immediately after transfection. For $A$ and $B$, error bars represent SEM; $n=3$. For $C$ and $D$, error bars represent the mean \pm range for two independent experiments.

\section{DISCUSSION}

This paper provides the first detailed study of the expression of polyglutamine-containing proteins in primary neurons. Transfection of polyglutamine-GFP fusion constructs into cerebellar granule neurons led to a length- and time-dependent aggregation of GFP. Although Q35-GFP aggregates were secreted or degraded by the cells, Q80-GFP expression resulted in death. The polyglutamine-induced death was accompanied by caspase activation. Although inhibition of caspases did not block the death, it delayed aggregation. Aggregation and cell death proceeded in the absence of the proapoptotic BCL-2 family member BAX and did not result in nuclear condensation. These data suggest that although the toxicity shared some characteristics of apoptosis, the death did not resemble classical apoptosis. Finally, addition of cAMP to transfected cells had a modest protective effect, allowing neurons with aggregates to survive longer than untreated cells.

\section{Characteristics of polyglutamine-GFP fusion protein aggregation and cell death}

Four polyglutamine-GFP constructs, Q19-GFP, Q35-GFP, Q56GFP, and Q80-GFP, were transfected into cerebellar granule 
A

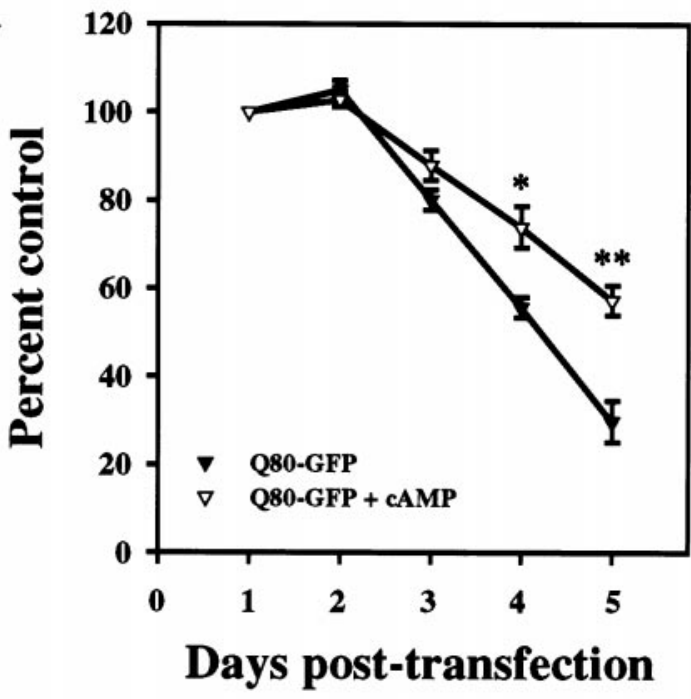

B

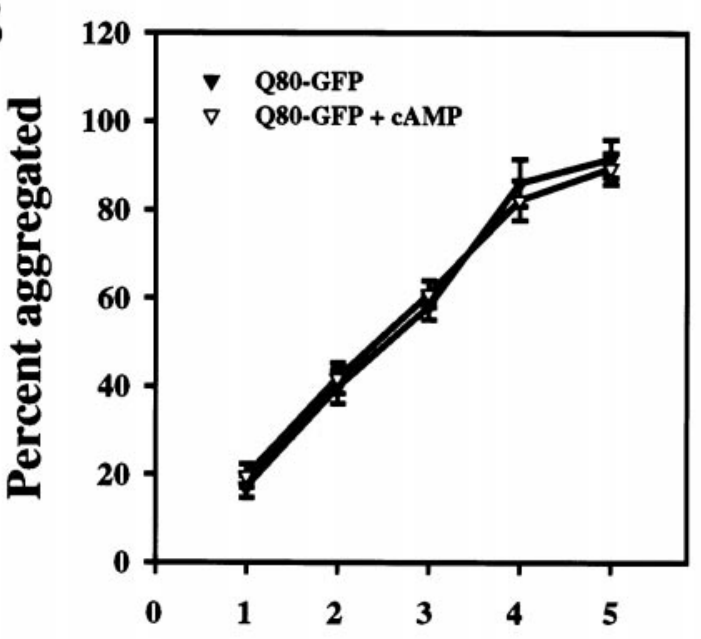

Days post-transfection
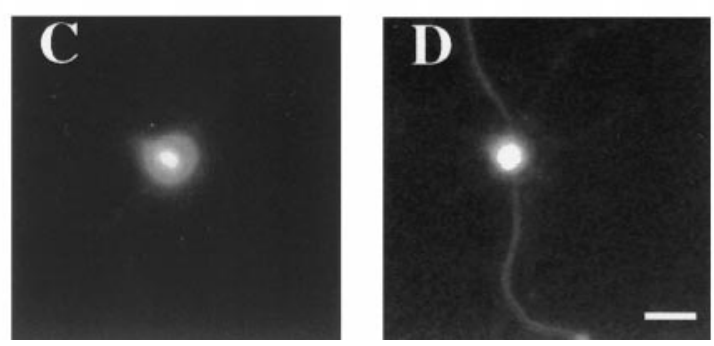

Figure 9. $\quad$ A $A M$ delays $Q 80-G F P$-induced toxicity. At $5 \mathrm{DIV}$, cerebellar granule neurons were transfected with $Q 80-G F P$ in the presence or absence of $800 \mu \mathrm{M} \mathrm{CPT-cAMP}$. Every $24 \mathrm{hr}$ for $5 \mathrm{~d}$ after transfection, the number of transfected cells present in designated fields and the number that contained fluorescent aggregates were counted. $A$, Data are presented as the number of transfected cells remaining in the field as a percentage of the original number. *, Statistically significant at $p=0.026 ;{ }^{* *}$, statistically significant at $p=0.009$. $B$, Data are presented as the percentage of cells at each time point that contained an aggregate. For both $A$ and $B$, error bars represent SEM; $n=3$. $C, D$, Photomicrographs were taken $4 \mathrm{~d}$ after transfection of cells expressing $Q 80-G F P$ in the presence $(D)$ or absence $(C)$ of $c A M P$. Note that cells maintained in the presence of $c A M P$ continue to show fluorescent neurites. Scale bar, $10 \mu \mathrm{m}$. neurons. These constructs were designed to model any of the polyglutamine-repeat diseases, because they lacked any additional sequence. Other culture systems have been used to characterize polyglutamine-containing protein expression (Ikeda et al., 1996; Brooks et al., 1997; Onodera et al., 1997; Paulson et al., 1997; Skinner et al., 1997; Abdullah et al., 1998; Igarashi et al., 1998; Martindale et al., 1998; Merry et al., 1998); however, the majority of this work involved expression of truncated constructs of the various disease genes in non-neuronal cell lines. Because the polyglutamine-repeat diseases are neurodegenerative disorders, the effects of expanded repeats in neurons may be different from those in non-neuronal cells. A truncated huntingtin construct does aggregate in primary cortical neurons (Martindale et al., 1998), but the aggregation and its effects have not been characterized.

Transfection of Q35-GFP, Q56-GFP, and Q80-GFP into primary neurons resulted in the appearance of fluorescent aggregates in a time- and length-dependent manner (Figs. 1, 2A). As seen in transgenic mouse models and diseased brain (Davies et al., 1997; DiFiglia et al., 1997; Ordway et al., 1997; Paulson et al., 1997; Skinner et al., 1997; Igarashi et al., 1998), aggregates localized to the nucleus (Fig. 1D) and were ubiquitinated (Fig. 5). Thus, the polyglutamine repeats alone were sufficient to confer nuclear localization and ubiquitin labeling.

The Q19-GFP construct was designed to be representative of wild-type protein, because normal individuals typically have fewer than 35 [CAG] repeat lengths in the various disease genes (for review, see Nance, 1997). Accordingly, Q19-GFP was never observed to aggregate in rat granule cells at the level of conventional fluorescence microscopy (Figs. $1 A, 2 A)$. Very small $(\ll 1$ $\mu \mathrm{m})$ aggregates could be seen by confocal microscopy in a small percentage of Q19-GFP-transfected cells 5 d after transfection, but these did not coalesce into larger aggregates (data not shown). These small aggregates were not seen in cells transfected with unmodified GFP.

The remainder of the studies focused on Q35-GFP and Q80GFP because of their relevance to human disease. Individuals with 31-39 [CAG] repeats in their huntingtin (or other) gene show a reduced penetrance for the disease, whereas an individual with 80 [CAG] repeats would develop juvenile HD (for review, see Nance, 1997). Both Q35-GFP and Q80-GFP formed aggregates in granule cells. However, the fact that Q80-GFP aggregates were larger (Fig. 4B), formed more rapidly (Fig. 2A), and achieved a greater total cell burden (Fig. 4) than did Q35-GFP aggregates provides intracellular evidence that the formation of aggregates is energetically more favorable for longer glutamine repeats. This hypothesis has been suggested previously by in vitro data (Perutz et al., 1994; Scherzinger et al., 1997; Georgalis et al., 1998).

Q35-GFP aggregates did not kill neurons but were instead secreted or degraded (Fig. $3 A$ ). These data, along with the observation by confocal microscopy that a small amount of aggregation occurred in Q19-GFP-transfected cells (see above), predict that some degree of aggregation may occur within all neurons. In this model, the neuron would survive as long as the polyglutamine-repeat length is small enough that the rate of aggregation is slower than the rate of degradation. Once the repeat length surpasses a pathogenic threshold, then the aggregate may become too large for the cell to dismantle before toxicity occurs. The mechanism by which degradation proceeds remains unclear, although the ubiquitin or proteasome pathway has been implicated. Aggregates were ubiquitinated in transfected granule 
cells (Fig. 5), similar to aggregates in transgenic mice (Davies et al., 1997; Ordway et al., 1997) and diseased brain (DiFiglia et al., 1997; Paulson et al., 1997; Skinner et al., 1997). Furthermore, the $20 \mathrm{~S}$ proteasome localizes to sites of polyglutamine aggregation (Cummings et al., 1998). These data and the fact that in all instances only one-half of the aggregates are ubiquitinated support the idea that aggregation precedes conjugation with ubiquitin.

\section{Polyglutamine toxicity is dissimilar to classical apoptosis}

One of the objectives of this study was to assess whether polyglutamine toxicity occurs by apoptosis. Caspases, cysteine proteases responsible for the terminal cleavage events in apoptosis, were activated in granule cells in response to polyglutamine aggregation by Q80-GFP (Fig. 6). However, inhibition of caspase activation did not block polyglutamine toxicity (Fig. 7). Toxicity also was not accompanied by condensation of nuclear chromatin and proceeded in the presence of the protein synthesis inhibitor cycloheximide (Fig. 8B). Furthermore, polyglutamine toxicity did not require the presence of the BCL-2 family member BAX (Fig. $8 A$ ), although $\mathrm{BAX}$ is essential for the death of granule cells in response to potassium deprivation (Miller et al., 1997a). For these reasons, polyglutamine toxicity cannot be labeled as classical apoptosis. The neuronal death in HD has been described as apoptotic, primarily on the basis that neurons within the striatum of HD patients are TUNEL-positive (Dragunow et al., 1995; Portera-Cailliau et al., 1995; Thomas et al., 1995). TUNEL staining reflects the $3^{\prime}-\mathrm{OH}$ ends that remain after DNA cleavage during apoptosis. However, TUNEL staining can be seen in the late stages of necrosis and, thus, should not be used as the sole criterion for apoptosis (Collins et al., 1992).

Because addition of the caspase inhibitor BAF does not prevent death of granule cells in response to potassium deprivation (Miller et al., 1997a), it was not surprising that BAF did not block the polyglutamine toxicity (Fig. $7 A$ ). In both paradigms, caspases are activated, but the neurons die a delayed death after addition of BAF. The partial protection by a caspase inhibitor is also similar to the incomplete rescue of an eye phenotype in a model of polyglutamine toxicity in Drosophila melanogaster by P35, a viral caspase inhibitor (Warrick et al., 1998). Finally, because only $12 \%$ of cells were immunoreactive for CM1 in the transfected granule cells (Fig. 6D), it remains possible that only $12 \%$ of cells initiated caspase activation. This would explain the inability of BAF to prevent the death of these cells. However, because CM1 immunoreactivity was a relatively late event and the cells went on to die (Fig. 6D), caspase activation was likely a transient event that occurred in all cells.

In addition, BAF was not acting only to counteract a cell death pathway in polyglutamine-transfected granule cells because addition of BAF also delayed aggregate formation (Fig. 7B). How caspases were influencing aggregation is not clear. BAF probably did not block cleavage of GFP itself because GFP has no putative caspase cleavage sites (data not shown). Therefore, BAF may have been affecting the cleavage of an unidentified component of the aggregates.

\section{Possible therapeutic applications}

Treatment of Q80-GFP-transfected cells with cAMP delayed the death induced by Q80-GFP aggregation. This delay was not caused by the ability of a cAMP-mediated pathway to promote degradation or clearance of aggregates (data not shown). Instead,
cAMP probably activated an additional trophic pathway. As possible evidence of this, addition of cAMP allowed for the maintenance of healthy neurites in Q80-GFP-transfected cells (Fig. 9C,D). cAMP, but not BDNF or IGF-I, may have been able to provide additional trophic support to granule neurons because cAMP activates distinct signaling pathways from potassium alone (Miller et al., 1997b). Because cAMP can provide trophic support in other neurons, including cortical and striatal neurons (Abiru et al., 1996; Ohgoh et al., 1998), agents that increase intracellular levels of cAMP may be candidates for further investigation in the treatment of neurons exposed to pathogenic huntingtin (or other) constructs.

Now and in the future, the analysis of the mechanisms of aggregation and toxicity in primary neurons will be important. Even though cerebellar granule neurons have not been shown to be affected in one of the known polyglutamine-repeat diseases, these cells are transfectable primary neurons that can be obtained in large numbers. Therefore, cerebellar granule neurons may provide a model system in which to test potential therapies for polyglutamine toxicity and to study further the pathogenic mechanisms in these diseases.

Note added in proof: While this paper was in review, Saudou et al. (Cell 95:55-66) reported the expression of mutant huntingtin constructs in primary neurons.

\section{REFERENCES}

Abdullah AAR, Trifiro MA, Panetraymond V, Alvarado C, Detourreil S, Frankel D, Schipper HM, Pinsky L (1998) Spinobulbar muscular atrophy - polyglutamine-expanded androgen receptor is proteolytically resistant in vitro and processed abnormally in transfected cells. Hum Mol Genet 7:379-384.

Abiru Y, Nishio C, Hatanaka H (1996) The survival of striatal cholinergic neurons cultured from postnatal 2-week-old rats is promoted by neurotrophins. Brain Res Dev Brain Res 91:260-267.

Armstrong RC, Aja TJ, Hoang KD, Gaur S, Bai X, Alnemri ES, Litwack G, Karanewsky DS, Fritz LC, Tomaselli KJ (1997) Activation of the CED3/ICE-related protease CPP32 in cerebellar granule neurons undergoing apoptosis but not necrosis. J Neurosci 17:553-562.

Brooks BP, Paulson HL, Merry DE, Salazar-Grueso EF, Brinkmann AO, Wilson EM, Fischbeck KH (1997) Characterization of an expanded glutamine repeat androgen receptor in a neuronal cell culture system. Neurobiol Dis 3:313-323.

Collins RJ, Harmon BV, Gobé GC, Kerr JFR (1992) Internucleosomal DNA cleavage should not be the sole criterion for identifying apoptosis. Int J Radiat Biol 61:451-453.

Cooper AJ, Sheu KF, Burke JR, Onodera O, Strittmatter WJ, Roses AD, Blass JP (1997) Polyglutamine domains are substrates of tissue transglutaminase: does transglutaminase play a role in expanded CAG/ poly-Q neurodegenerative diseases? J Neurochem 69:431-434.

Cummings CJ, Mancini MA, Antalffy B, Defranco DB, Orr HT, Zoghbi HY (1998) Chaperone suppression of aggregation and altered subcellular proteasome localization imply protein misfolding in SCA1. Nat Genet 19:148-154.

Davies SW, Turmaine M, Cozens BA, DiFiglia M, Sharp AH, Ross CA, Scherzinger E, Wanker EE, Mangiarini L, Bates GP (1997) Formation of neuronal intranuclear inclusions underlies the neurological dysfunction in mice transgenic for the HD mutation. Cell 90:537-548.

Deckwerth TL, Elliott JL, Knudson CM, Johnson Jr EM, Snider WD, Korsmeyer SJ (1996) BAX is required for neuronal death after trophic factor deprivation and during development. Neuron 17:401-411.

DiFiglia M, Sapp E, Chase KO, Davies SW, Bates GP, Vonsattel JP, Aronin N (1997) Aggregation of huntingtin in neuronal intranuclear inclusions and dystrophic neurites in brain. Science 277:1990-1993.

D'Mello SR, Galli C, Ciotti T, Calissano P (1993) Induction of apoptosis in cerebellar granule neurons by low potassium: inhibition of death by insulin-like growth factor I and cAMP. Proc Natl Acad Sci USA 90:10989-10993.

Dragunow M, Faull RL, Lawlor P, Beilharz EJ, Singleton K, Walker EB, Mee E (1995) In situ evidence for DNA fragmentation in Hunting- 
ton's disease striatum and Alzheimer's disease temporal lobes. NeuroReport 6:1053-1057.

Duyao MP, Auerbach AB, Ryan A, Persichetti F, Barnes GT, McNeil SM, Ge P, Vonsattel JP, Gusella JF, Joyner AL (1995) Inactivation of the mouse Huntington's disease gene homolog Hdh. Science 269: 407-410.

Georgalis Y, Starikov EB, Hollenbach B, Lurz R, Scherzinger E, Saenger W, Lehrach H, Wanker EE (1998) Huntingtin aggregation monitored by dynamic light scattering. Proc Natl Acad Sci USA 95:6118-6121.

Hervás JP, Berciano MT, Silos I, Lafarga M (1990) A morphometric ultrastructural study of the nucleus of cerebellar granule cells. Acta Anat 139:5-10.

Igarashi S, Koide R, Shimohata T, Yamada M, Hayashi Y, Takano H, Date H, Oyake M, Sato T, Sato A, Egawa S, Ikeuchi T, Tanaka H, Nakano R, Tanaka K, Hozumi I, Inuzuka T, Takahashi H, Tsuji S (1998) Suppression of aggregate formation and apoptosis by transglutaminase inhibitors in cells expressing truncated DRPLA protein with an expanded polyglutamine stretch. Nat Genet 18:111-117.

Ikeda H, Yamaguchi M, Sugai S, Aze Y, Narumiya S, Kakizuka A (1996) Expanded polyglutamine in the Machado-Joseph disease protein induces cell death in vitro and in vivo. Nat Genet 13:196-202.

Kahlem P, Terre C, Green H, Djian P (1996) Peptides containing glutamine repeats as substrates for transglutaminase-catalyzed cross-linking: relevance to diseases of the nervous system. Proc Natl Acad Sci USA 93:14580-14585.

Knudson CM, Tung KS, Tourtellotte WG, Brown GA, Korsmeyer SJ (1995) Bax-deficient mice with lymphoid hyperplasia and male germ cell death. Science 270:96-99.

Kuida K, Zheng TS, Na S, Kuan C, Yang D, Karasuyama H, Rakic P, Flavell RA (1996) Decreased apoptosis in the brain and premature lethality in CPP32-deficient mice. Nature 384:368-372.

La Spada AR, Wilson EM, Lubahn DB, Harding AE, Fischbeck KH (1991) Androgen receptor gene mutations in X-linked spinal and bulbar muscular atrophy. Nature 352:77-79.

Levi G, Aloisi F, Ciotti MT, Gallo V (1984) Autoradiographic localization and depolarization-induced release of acidic amino acids in differentiating cerebellar granule cell cultures. Brain Res 290:77-86.

Martindale D, Hackam A, Wieczorek A, Ellerby L, Wellington C, McCutcheon K, Singaraja R, Kazemi-Esfarjani P, Devon R, Kim SU, Bredesen DE, Tufaro F, Hayden MR (1998) Length of huntingtin and its polyglutamine tract influences localization and frequency of intracellular aggregates. Nat Genet 18:150-154.

Matilla A, Koshy BT, Cummings CJ, Isobe T, Orr HT, Zoghbi HY (1997) The cerebellar leucine-rich acidic nuclear protein interacts with ataxin-1. Nature 389:974-978.

Merry DE, Kobayashi Y, Bailey CK, Taye AA, Fischbeck KH (1998) Cleavage, aggregation and toxicity of the expanded androgen receptor in spinal and bulbar muscular atrophy. Hum Mol Genet 7:693-701.

Miller TM, Johnson Jr EM (1996) Metabolic and genetic analyses of apoptosis in potassium/serum-deprived rat cerebellar granule cells. J Neurosci 16:7487-7495.

Miller TM, Moulder KL, Knudson CM, Creedon DJ, Deshmukh M, Korsmeyer SJ, Johnson Jr EM (1997a) Bax deletion further orders the cell death pathway in cerebellar granule cells and suggests a caspaseindependent pathway to cell death. J Cell Biol 139:205-217.

Miller TM, Tansey MG, Johnson Jr EM, Creedon DJ (1997b) Inhibition of phosphatidylinositol 3-kinase activity blocks depolarization- and insulin-like growth factor I-mediated survival of cerebellar granule cells. J Biol Chem 272:9847-9853.

Namura S, Zhu JM, Fink K, Endres M, Srinivasan A, Tomaselli KJ, Yuan JY, Moskowitz MA (1998) Activation and cleavage of caspase-3 in apoptosis induced by experimental cerebral ischemia. J Neurosci 18:3659-3668

Nance MA (1997) Clinical aspects of CAG repeat diseases. Brain Pathol 7:881-900.

Nasir J, Floresco SB, O’Kusky JR, Diewert VM, Richman JM, Zeisler J, Borowski A, Marth JD, Phillips AG, Hayden MR (1995) Targeted disruption of the Huntington's disease gene results in embryonic lethality and behavioral and morphological changes in heterozygotes. Cell 81:811-823.
Ohgoh M, Kimura M, Ogura H, Katayama K, Nishizawa Y (1998) Apoptotic cell death of cultured cerebral cortical neurons induced by withdrawal of astroglial trophic support. Exp Neurol 149:51-63.

Onodera O, Burke JR, Miller SE, Hester S, Tsuji S, Roses AD, Strittmatter WJ (1997) Oligomerization of expanded-polyglutamine domain fluorescent fusion proteins in cultured mammalian cells. Biochem Biophys Res Commun 238:599-605.

Ordway JM, Tallaksen-Greene S, Gutekunst CA, Bernstein EM, Cearley JA, Wiener HW, Dule LS, Lindsey R, Hersch SM, Jope RS, Albin RL, Detloff PJ (1997) Ectopically expressed CAG repeats cause intranuclear inclusions and a progressive late onset neurological phenotype in the mouse. Cell 91:753-763.

Paulson HL, Perez MK, Trottier Y, Trojanowski JQ, Subramony SH, Das SS, Vig P, Mandel JL, Fischbeck KH, Pittman RN (1997) Intranuclear inclusions of expanded polyglutamine protein in spinocerebellar ataxia type 3. Neuron 19:333-344.

Perutz MF, Johnson T, Suzuki M, Finch JT (1994) Glutamine repeats as polar zippers: their possible role in inherited neurodegenerative diseases. Proc Natl Acad Sci USA 91:5355-5358.

Portera-Cailliau C, Hedreen JC, Price DL, Koliatsos VE (1995) Evidence for apoptotic cell death in Huntington disease and excitotoxic animal models. J Neurosci 15:3775-3787.

Ramón y Cajal S (1911) Histologie du système nerveux de l'homme et des vertébrés. Paris: Maloine.

Ross CA (1997) Intranuclear neuronal inclusions: a common pathogenic mechanism for glutamine-repeat neurodegenerative diseases? Neuron 19:1147-1150.

Scherzinger E, Lurz R, Turmaine M, Mangiarini L, Hollenbach B, Hasenbank R, Bates GP, Davies SW, Lehrach H, Wanker EE (1997) Huntingtin-encoded polyglutamine expansions form amyloid-like protein aggregates in vitro and in vivo. Cell 90:549-558.

Segal RA, Takahashi H, McKay RD (1992) Changes in neurotrophin responsiveness during the development of cerebellar granule neurons. Neuron 9:1041-1052.

Sharp AH, Ross CA (1996) Neurobiology of Huntington's disease. Neurobiol Dis 3:3-15.

Skinner PJ, Koshy BT, Cummings CJ, Klement IA, Helin K, Servadio A, Zoghbi HY, Orr HT (1997) Ataxin-1 with an expanded glutamine tract alters nuclear matrix-associated structures. Nature 389:971-974.

Srinivasan A, Roth KA, Sayers RO, Shindler KS, Wong AM, Fritz LC, Tomaselli KJ (1998) In situ immunodetection of activated caspase-3 in apoptotic neurons in the developing nervous system. Cell Death Diff, in press.

Thomas LB, Gates DJ, Richfield EK, O'Brien TF, Schweitzer JB, Steindler DA (1995) DNA end labeling (TUNEL) in Huntington's disease and other neuropathological conditions. Exp Neurol 133:265-272.

Thornberry NA (1997) The caspase family of cysteine proteases. Br Med Bull 53:478-490.

Warrick JM, Paulson HL, Grayboard GL, Bui QT, Fischbeck KH, Pittman RN, Bonini NM (1998) Expanded polyglutamine protein forms nuclear inclusions and causes neural degeneration in Drosophila. Cell 93:939-949.

Wexler NS, Young AB, Tanzi RE, Travers H, Starosta-Rubinstein S, Penney JB, Snodgrass SR, Shoulson I, Gomez F, Ramos Arroyo MA (1987) Homozygotes for Huntington's disease. Nature 326:194-197.

White FA, Keller-Peck CR, Knudson CM, Korsmeyer SJ, Snider WD (1998) Widespread elimination of naturally occurring neuronal death in Bax-deficient mice. J Neurosci 18:1428-1439.

Woo M, Hakem R, Soengas MS, Duncan GS, Shahinian A, Kagi D, Hakem A, McCurrach M, Khoo W, Kaufman SA, Senaldi G, Howard T, Lowe SW, Mak TW (1998) Essential contribution of caspase 3/CPP32 to apoptosis and its associated nuclear changes. Genes Dev 12:806-819.

Xia Z, Dudek H, Miranti CK, Greenberg ME (1996) Calcium influx via the NMDA receptor induces immediate early gene transcription by a MAP kinase/ERK-dependent mechanism. J Neurosci 16:5425-5436.

Zeitlin S, Liu JP, Chapman DL, Papaioannou VE, Efstratiadis A (1995) Increased apoptosis and early embryonic lethality in mice nullizygous for the Huntington's disease gene homologue. Nat Genet 11:155-163. 